\title{
European Legal Protection of Employees' Health Working with Nanoparticles in the Context of the Christian Vision of Human Work
}

\author{
Maciej Jarota
}

Received: 14 March 2020 / Accepted: 24 January 2021 / Published online: 11 June 2021

(C) The Author(s) 2021

\begin{abstract}
The article analyses European regulations concerning the health protection at work with nanomaterials in the context of the Christian vision of human work. The increasingly widespread presence of nanotechnology in workplaces requires serious reflection on the adequacy of employers' measures to protect workers' health from the risks in the workplace. The lack of clear guidance in European legislation directly concerning work with nanoparticles is problematic. Moreover, the health consequences for workers using nanomaterials in the work process are not fully explored in science. It is therefore essential to consider what values should accompany employers in shaping working conditions and what values should be legislated when creating occupational health and safety (OH\&S) law. First of all, how should the employers deal with the unknown? Should they abandon nanomaterials for which they do not have adequate information at all until the consequences for workers' health have been established? Should such action be limited to situations where studies indicate the toxicity of the nanomaterials present in the working environment? In this context, the article analyses values and objectives indicated by the teaching of the Catholic Church. The publication presents a Christian
\end{abstract}

M. Jarota $(\bowtie)$

Department of Labour Law and Social Insurance, Faculty of Law, Canon Law and Administration, The John Paul II Catholic University of Lublin, Aleje Racławickie 14, 20-950 Lublin, Poland e-mail: m.jarota@kancelariajarota.pl vision on the protection of workers' health and their place in the work process. Europe has been under the influence of Christianity for many centuries now. The Catholic Church's view of human labour continues to be present in public debates in Europe. The Christian view of human labour is focused on the working man and his dignity. Irrespective of other concepts of labour, Christianity assumes the priority of a human being over capital. The Catholic Church analyses the working man as going beyond the Earthly context, which is not typical for such doctrines as liberalism or Marxism. The author's article is an attempt in answering the question about how up to date the Catholic Church's views on human labour are in the light of nanotechnology development in the workplace.

Keywords Nanotechnology · Work and safety · Working condition $\cdot$ Christian vision of human work

\section{Introduction}

Working with nanoparticles is an important element of the field nanotechnology [1] that is predicted to have far-reaching social and economic impacts ([2], p. 90).

The intensive development of nanotechnology in the work process gives rise to considerations regarding the health and safety of workers in the nanotechnology environment. These should, in turn, be assessed from 
the viewpoint of a Christian concept of the protection of human labour.

In ethics literature, nanotechnology is analysed with respect to a variety of risks ([3], p. 25). Among other things, the risks and health opportunities associated with the use of nanomaterials or ethical issues related to patent protection of nanotechnology achievements are examined [4]. In addition, nanomedicine, which allows better diagnoses of a patient's health condition or to deliver medication, raises various ethical questions [5].

In order to analyse issues related to working with nanoparticles, the concept of nanomaterials should be established. At the European Union level, Regulation (EU) 2017/745 of the European Parliament and of the Council of 5 April 2017 on medical devices, amending Directive 2001/83/EC, Regulation (EC) No 178/2002 and Regulation (EC) No 1223/2009 and repealing Council Directives 90/385/EEC and 93/42/EEC [6], sets out that "nanomaterial" means a natural, incidental or manufactured material containing particles in an unbound state or as an aggregate or as an agglomerate and where, for $50 \%$ or more of the particles in the number size distribution, one or more external dimensions in a size range of 1-100 nm (see more widely [7], pp. 634-635). This legislation also establishes the concept of a nanoparticle, which is a piece of matter with defined physical boundaries. Such particles may form agglomerates or aggregates. Fullerenes, graphene flakes and single-wall carbon nanotubes with one or more dimensions below $1 \mathrm{~nm}$ should be considered as nanomaterials (art. $2 \mathrm{pkt}$ 18 [6]). European legislation has also defined a manufactured nanomaterial, which is any intentionally produced material that has one or more dimensions of the order of $100 \mathrm{~nm}$ or less. Alternatively, it is composed of discrete functional parts, either internally or at the surface, many of which have one or more dimensions of the order of $100 \mathrm{~nm}$ or less, including structures, agglomerates or aggregates, which may have a size above the order of $100 \mathrm{~nm}$ but retain properties that are characteristic of the nanoscale [8]. According to the Commission Recommendation of 8 October 2011 on the definition of nanomaterial 2011/696/EU, in cases justified by environmental protection, safety or competition considerations, the threshold value being $50 \%$ of decay may be substituted with a value between 1 and 50\% [9].

Generally, nanomaterials are considered to be particles sized between ca. 1 and $100 \mathrm{~nm}(\mathrm{~nm})$. However, their difference from other materials is essential to fully understanding their significance. Their properties may differ from those of larger particles [10]. Nanomaterials have a variety of properties such as hardness and ductility of metals and alloys, plasticity and superplasticity of ceramics (mechanical) or enhanced selectivity, empty carrier spheres for specific drugs and their controlled release (sterical) ([11], p. 58). The Scientific Committee on Engineering and Newly Identified Health Risks (SCENIHR) [12] emphasises the characteristics of nanomaterials, indicating that they are materials with one or more external dimensions or internal structures that demonstrate new properties as compared with same materials not in the nanoscale ([13], p. 117). In this context, in order for the nanomaterial to be considered as such, the dimensions of the material are of lesser importance, as opposed to specific properties of such materials ([13], p. 117).

\section{Legal Aspects of the Use of Nanoparticles in the Workplace}

At the international level, there is no health and safety legislation directly related to the use of nanomaterials. However, one can note, for example, the activities of the International Organisation for Standardisation (ISO), which has, inter alias, defined nanotechnology with ISO/TC 229 standards ([14], pp. 127-128). Moreover, proposals for harmonised elements of chemical hazard communication are included in the Globally Harmonized System of Classification and Labelling of Chemicals (GHS) [15].

The relevant EU regulations apply to the safety of the use of nanomaterials, but they also do not define working rules directly related to the work with nanomaterials. The main legal act setting out the general obligations of the employer to protect the health of the employee is Council Directive 89/391/EEC of 12 June 1989 on the introduction of measures to encourage improvements for the safety and health of workers at the workplace [16]. According to Article 5(1) of Directive 89/391/EEC, the employer is responsible for ensuring the health and safety of workers in every aspect related to their work. Within the meaning of Article 6(1) of that Directive, the employer shall take necessary measures to ensure the safety and health protection of workers, including the prevention of occupational risks and provision of information and training and the provision of the necessary organisation 
and means. The employer shall be alert to the need for adjusting these measures to take into account any changing circumstances and aim to improve existing situations. However, these measures should: be based on general principles concerning avoiding risks; evaluating the risks which cannot be avoided; combating the risks at source; adapting the work to the individual, especially as regards the design of workplaces, the choice of work equipment and the choice of working and production methods, with a view, in particular, to alleviating monotonous work and work at a predetermined work rate and to reducing their effect on health; adapting to technical progress; replacing the dangerous with the non-dangerous or the less dangerous; developing a coherent overall prevention policy which covers technology, organisation of work, working conditions, social relationships and the influence of factors related to the working environment (art. 6(2) [16]). In addition, the EU Legislator has adopted, in Article 6(2) of Directive 89/391/EEC, the rule that collective protection measures shall be given priority over individual protective measures and that the employer shall provide workers with appropriate instructions. It is also important to remember that in a working environment where chemicals are used, the employer must prepare a risk assessment. Pursuant to Article 6(3) of Directive 89/391/EEC, in accordance with that assessment and to the extent necessary, the preventive measures and the production and working methods implemented by the employer must assure, in particular, an improvement in the level of protection afforded to workers with regard to health and safety. In addition, the employer should ensure that the planning and implementation of new technologies are subject to consultation with workers or their representatives as regards the consequences of the choice of equipment, the working conditions and the working environment for the health and safety of workers (art. 6(3) [16]).

The health and safety sphere are also regulated by, inter alia, Council Directive 98/24/EC of 7 April 1998 on the protection of the health and safety of workers from the risks related to chemical agents at work [17]. By the power of Article 4(1) thereof, the employer shall first determine whether hazardous chemical agents are present in the workplace and then assess the risks to the safety and health of workers arising from their presence. The employer, in the light of Article 5(2)(a) of the abovementioned Directive, must also take measures to eliminate or reduce minimum health risks to workers exposed to hazardous chemical agents by, among other things, properly designing and organising systems of work at the workplace. In addition, article 32 of the Corrigendum to Regulation (EC) No 1907/2006 of the European Parliament and of the Council of 18 December 2006 concerning the Registration, Evaluation, Authorisation and Restriction of Chemicals (REACH), establishing a European Chemicals Agency, amending Directive 1999/45/EC and repealing Council Regulation (EEC) No 793/93 and Commission Regulation (EC) No 1488/94 as well as Council Directive 76/769/EEC and Commission Directives 91/155/EEC, 93/67/EEC, 93/105/EC and 2000/21/EC [18] sets out the information obligations of the supplier of the substance to downstream actors in the supply chain. The abovementioned Regulation (EC) 1907/2006 was amended by Commission Regulation (EU) 2018/1881 of 3 December 2018 amending Regulation (EC) No 1907/2006 of the European Parliament and of the Council on the Registration, Evaluation, Authorisation and Restriction of Chemicals (REACH) as regards Annexes I, III, VI, VII, VIII, IX, X, XI and XII to address nanoforms of substances [19]. Within the European Union, the following also apply Regulation (EC) No 1272/2008 of the European Parliament and of the Council of 16 December 2008 on classification, labelling and packaging of substances and mixtures, amending and repealing Directives 67/548/EEC and 1999/45/EC and amending Regulation (EC) No 1907/2006 (CLP Regulation Classification, Labelling and Packaging) [20]. ${ }^{1}$ It establishes rules for communicating the risks associated with the use of products through appropriate marking.

\footnotetext{
1 The rules for dealing with specific factors in work environments specifies [21]. For the different types of substances in the European Union, the level of health protection for working with chemical agents is also defined in [11]. According to Art. 6(3) and Art. 9(1) Directive 89/391/EEC [10], the employer determines whether hazardous chemical agents are present at the workplace and, if so, assesses the risks to the safety and health of workers arising from the presence of those agents, taking into account certain elements of Art 4(1) of Council Directive 98/24/EC [17]. The European Union also has a Directive 2004/37/EC of the European Parliament and of the Council [22].
} 
The EU regulations presented above do not specify the applicable limit values for the concentration of nanoparticles at daily and weekly working hours, taking into account the specific nature of the nano fraction. European legislation does not propose individual and general protection measures for working with nanomaterials. The Directive 89/391/EEC introduces only the general principles of health and safety, assuming that general measures for the protection of workers' health should be applied as a priority compared with individual measures. It introduces, of course, several health and safety obligations for the employer, including the obligation to prepare an appropriate risk assessment, but without specifying how to respond precisely to risks for working with nanoparticles. European legislation requires employers to use the appropriate tools to take account of scientific and technological progress, but it is up to them to determine precisely what measures to take. In practice, ensuring appropriate working conditions can prove to be very difficult due to the specific nature of nanoparticles, which in some cases result in extraordinary durability of a given element (see [23], p. 76), but which have a non-standard size and in some situations may show increased toxicity or new properties not present in large-sized materials. The difficulty is that there are non-uniform test methods used to determine parameters for exposure to nanoparticles (see [7], p. 639) and differentiation of nanomaterials ([24], p. 5). The main problem, therefore, is that due to the specific nature of nanoparticles, it is difficult to determine the appropriate parameters for exposure to them in the working environment ([25], p. 10) ${ }^{2}$ The toxicity of nanoparticles is a complex issue; it may be caused by various properties, such as their size, chemical composition and shape. In addition, it may depend on the surface properties, their charge, surface area and reactivity ([27], pp. 501-502). The fact that not all types of nanomaterials have an adverse effect on workers' health further complicates the matter ([28], pp. 315-316). It would be difficult to include specific exposure limits for individual nanomaterials, for example, in Directive 89/391/EEC, which is essentially of a general descriptive nature. Instead,

\footnotetext{
${ }^{2}$ For more on occupational health and safety in a work environment involving nanoparticles, see [26], p. 42-56. More on the risks of working with nanoparticles in: [7], p. 639-640.
}

European standards for confirmation of given nanomaterial toxicity should be worked out, and countries obligated, on confirmation of such toxicity, to provide adequate levels of occupational health and safety $(\mathrm{OH} \& \mathrm{~S})$ for work with such nanomaterials.

Due to incomplete knowledge of nanomaterial properties, especially with regards to the safety of work with nanomaterials, the literature ([29], pp. 53-54, [30], pp. 32-33) points to the adoption of the prudence principle in working environments utilising nanomaterials. This principle is expressed in Article 191(1). The EU Treaty [31] states that the European Union environmental policy should contribute to the protection of human health. Although the rule here primarily refers to the environment, its interpretations range far and wide. It is defined as the general principle that requires competent bodies to take relevant measures to prevent potential threats to public health [32]. According to the case law, it takes precedence over economic interests [32]. This principle may be referred to when identifying potentially adverse consequences of a phenomenon and scientific assessment of risks, which due to an insufficiency of data and their inconclusive or inaccurate nature prevents the formulation of an unambiguous position. When faced witha risk, deciding whether to respond to a threat under the prudence principle should be preceded, in the European Commission's view, with an assessment into the potential consequences of staying idle and referring to the uncertainty of scientific assessment. The response should be proportional to the threat. First and foremost, measures adopted should be proportional to the desired protection level. The Commission points out that in some cases, total prohibition may be an inadequate, too radical response, whereas in other cases, it might be the only possible response to the potential risk [33].

A cautious approach to new threats also exists in individual European countries. For example, employers in Italy were obligated to update their risk assessments so that they reflect developments in science and technology. This obligation applies even when adverse consequences of specific factors to workers' health have not even been fully confirmed ([34], p. 526). Polish legislation does not include laws applicable to nanotechnology. However, the Legislator adopted the principle of formulating workplace conditions based on scientific studies. The employer is obliged to protect the life and health of employees 
by ensuring safe and healthy working conditions by adopting scientific and technological achievements (art. 207(2) [35]).

Meanwhile, in the work with nanoparticles, the main risks concern workers involved in the processing of nanosubstances ([36], p. 594). They are related to the release of particles, which can sometimes be pathogenic ([37], p. 503). Employees who are in such a nanoparticle environment are at risk ([38], p. 419). Often, the nanoparticles are not entirely known, but they can be dangerous for the worker, although the risk may be related only to some nanomaterials ([39], p. 285). For example, carbon nanotubes in a particular concentration are harmful to human health ([37], p. 503). Iron oxide nanomaterials may have toxic properties, although they can be helpful in disinfecting equipment ([40], p. 194).

Therefore, how should an employer react to such threats? What values should the employer be guided by when legal regulations oblige him to introduce appropriate working conditions, but specific guidelines do not exist. What should be the employer's practice in terms of ensuring occupational health and safety to employees? How to reduce the risks in the work environment? Recommendations from Catholic social teaching can be helpful in this regard.

\section{The Christian Vision of Protecting Human Labour}

The protection of worker's health was already analysed in the first papal encyclical Rerum Novarum of Leo XIII. The Pope pointed out that human fitness, like nature, has its limits. Employers should, therefore, ensure that working time does not exceed a specific norm in any $24 \mathrm{~h}$ period and that the worker is provided with an adequate break to rest. The Holy Father emphasised that some work can be more dangerous to health than other work, pointing to work underground. Therefore, the type of work must be taken into account when shaping the working conditions [41]. The importance of respecting the health of the worker was pointed out by Paul VI in the Pastoral Constitution on the Church in the modern world Gaudium et Spes, emphasising that inhumane working conditions, where man is treated as a mere instrument of profit, are incompatible with the teachings of Christ [42].
Moreover, John XXIII wrote about the right to life, which is imminently connected with the protection of human health in his encyclical Pacem in Terris. According to the Pope, working conditions should be designed in such a way that, in particular, the physical strength of the worker is not weakened [43]. Paul VI, in his encyclical Populorum Progressio, pointed out that the development of individual people and the whole of humanity without accepting a true hierarchy of values can lead to many dangers. In his opinion, in particular, the desire for profit must not be allowed to undermine the human being [44]. Development is also a search for spiritual values, such as love, friendship, prayer and contemplation ([45], p. 20). John Paul II, in his encyclical Redemptor Hominis, emphasised that such a development demands a proportional improvement in morality and ethics to make life on earth more human [46]. These words were, in a way, a proclamation of the greatness of man when contemporary civilisation seems to reduce man from a goal to an object ([47], p. 46). The Pope's vision was about man as a human being who is the work of the creation of God ([48], pp. 28-29).

John Paul II decidedly put a priority of an employee over matter, which is expressed in the encyclical about human work Laborem Exercens. Deriving from the biblical phrase "Be fruitful and multiply, and fill the earth and subdue it", he pointed out that work has an ethical dimension, due to the fact that the one who does it (man) is a human being [49]. Human industriousness combined with work order can be a model to prevent degradation of an employee, especially the loss of physical strength or proper dignity and subjectivity [49]. It is worth noting that this encyclical was written during the communist regime, especially in the countries of Central and Eastern Europe, but its significance is also valid today. The guidelines on work ethics still remain valid, only the nature of health and safety risks in connection with the development of science and technology in the work process changes. During this period, other representatives of the Catholic Church also pointed to the problem of worker health protection. A notable example is the Polish Cardinal Stefan Wyszyński, who cooperated with John Paul II. This Primate of Poland drew attention to the state of health of women working in factories, who may feel dyspnoea as a result of particular dust at work ([50], pp. 165-166). 
How timely do such concerns appear to be in the context of released asbestos dust, or some of the carbon nanotubes whose toxic effects have been confirmed by scientific studies? Unfortunately, the problem of working with nanoparticles is not well recognised, and their effects may be invisible to the eye, making it difficult to take the right approach to risks.

\section{How to Deal With the Unknown: Adopt a Radically Cautious Approach or Only Act in Scientifically Confirmed Situations?}

In the context of the Christian vision of the protection of human health, consideration should be given to how to respond to the challenges of occupational health and safety of workers. First of all, a decision should be made as to whether to take a very cautious approach here, leading even to the abandonment of nanomaterials until the extent of their impact on workers has been established, or to take such action only when studies clearly indicate the toxicity of nanomaterials. Both the employer and the Legislator are faced with those questions since the protection of worker's health in a working environment utilising nanomaterial requires an adequate response by both parties. It is the employer that shapes the level of occupational health and safety under the relevant in-house policy and $\mathrm{OH} \& \mathrm{~S}$ principles. The Legislator is responsible for common law binding to the employer. It should account for new threats related to the development of nanotechnology, although it would be difficult to cover each and every situation at any specific plant.

On the one hand, it can be pointed out that the development of nanotechnology helps, for example in medicine, by creating an opportunity for people who are ill to improve their health ([23], p. 76). Indeed, many nanomaterials are used in medicine, and their influence in various supportive therapies in a patient's treatment is commonly observed. Some drugs cause side effects, but they still obtain marketing authorisations due to their overall positive effect in a specific condition. A complete recall of pharmacological agents that help people is not considered. The use of nanomaterials in the work environment should not be held back a priori when scientific studies have not unambiguously confirmed potential human health concerns. Only a clear position of scientists should influence the policy of the Legislator and employers in the field of health and safety of workers. The Legislator should draft laws taking into account the general rules of conduct when nanomaterials are found to be toxic. Employers, on the other hand, should protect the health and life of workers by ensuring safe and hygienic working conditions with the appropriate use of scientific and technological achievements. However, this does not mean that it would be necessary to automatically ban the use of specific nanomaterials in a situation where their adverse effects on the human body have not yet been confirmed by scientific research. Such measures could have a negative impact not only on the interests of the employer but above all on the development of the entire field of nanotechnology, which generally serves people in many respects. It should never be forgotten that the use of nanomaterials in medicine enables innovative treatment of serious conditions [51]. In connection with the use of nanomaterials to improve human health, each situation should be carefully analysed on a case-by-case basis, taking into account the consequences of possible discontinuation of their use and the risks in the work environment. When considering a recall of any nano-object, all aspects should be taken into account, including its specific nature and ramifications of suspending work with the use of a given nanomaterial.

On the other hand, it should not be forgotten that it is man who should be the most important in the work process, and therefore, the protection of the worker's health in the nano environment should be a priority. The protection of the worker's physical and spiritual health in the work process should be ensured first and foremost [49]. The Catholic Church points out that " $[\mathrm{t}]$ he development of technology and the development of contemporary civilisation, which is marked by the ascendancy of technology, demand a proportional development of morals and ethics" [46]. Clearly man's control over material things indicates that ethics take precedence over technology, the spirit over matter and the person over the thing. These primary values result precisely from the biblical statement: "Make the earth subject to yourselves" [46]. Man should remain the target of scientific and technological progress ([52], pp. 153-157). According to John Paul II, it is to be done in man, for man and through him [49].

However, the introduction of strong protection measures in working with nanomaterials may cause resistance from business stakeholders and may 
conflict with the benefits of nanotechnology ([53], p. 35). The doctrine of the Catholic Church may be an answer to these business doubts. Benedict XVI pointed out that the interest of the economy also of large enterprises cannot cause the violation of employee rights [54]. It is the employer's primary responsibility to ensure that the conditions of health and safety at work are adequate. The essential value should remain the human being, so their health requires an appropriate response to the risks involved in specific situations. Catholic Social Teaching indicates that human dignity should be the focus of attention. Work has priority over capital because it is closely linked to the human being. Therefore, directors and other persons holding managerial positions in large companies should not only be guided by profit, but also by the interests of the workforce ([55], pp. 232-233).

Does this mean that work involving nanomaterials or nanoparticles should be stopped by the Legislator as soon as possible? It seems that at the current stage of nanotechnology development when the issue of the toxicity of nanomaterials is not fully recognised, far-reaching precautions should be taken when working with nanoparticles. Of course, action cannot automatically be taken to prohibit the use of all nanomaterials in work environments. Their use can be very beneficial, among other things, from the perspective of medical applications. However, in the absence of an unambiguous position of science on the toxicity of specific nanomaterials, it is necessary to adopt, at least temporarily, some worker protection measures. Such actions seem to be consistent with the position of the European Commission on the application of the prudence principle. The Commission points out that adopted protection measures should be maintained until complete scientific evidence is published. The adopted protection measures should correspond individually with a specific nanomaterial which was subjected to studies and not just with all existing nanomaterials collectively.

However, it seems that the mere adoption of the prudence principle resulting from Article 191 of the EU Treaty may be insufficient. The European Legislator should define a suitable model for proceeding in the event that the potential risk for adverse effects of a specific nanomaterial to human health is disclosed but not yet thoroughly studied. Considering the priority of man over matter, the Legislator should introduce legal mechanisms obligating the employer to suspend the workplace use of any specific nanomaterial in the workplace until the impact of the nanomaterial on workers in the work environment is thoroughly analysed. Then, employers could implement such a mechanism in their practice. This would permit ensuring an adequate level of health protection for workers in the work environment. Legislation should aim to protect the worker as a higher value than the profit from nanotechnology. Risks that are already known and studied should be eliminated. In the case of scientific doubts whether a given substance is toxic according to the principle of human priority over matter, the employer should not use the nanomaterials concerned.

Employers have a number of methods to reduce a worker's exposure to nanoparticles that are harmful to their health. They may use general measures, such as efficient filtration and ventilation of the workplace, or typical personal protective equipment used to reduce exposure to nanomaterials, for instance, masks and protective gloves. The methods chosen should be adapted to the confirmed risks so as not to generate unnecessary costs. In addition, the risks associated with the use of nanotechnology in the work environment should be immediately reduced as much as possible in the event of any publication of scientific studies showing the toxicity of the nanomaterial concerned. Whenever doubts arise as to human safety in the workplace, the principle that man is more important than matter must be followed. The health and life of a person should always remain the aim of work, as indicated by John Paul II, among others. Therefore, in certain situations employers should block or abandon the release of nanoparticles in the work process. Protection of human health and life requires from the employer a cautious approach to $\mathrm{OH} \& \mathrm{~S}$. Human beings may not be a mere object of nanotechnology development but its goal. The use of nanomaterials must involve caring about human interests, especially the interest of the creator-the worker. It is the worker who uses nanomaterials with the end goal that others could benefit from their unique properties. However, the worker must not suffer more significant risks in the workplace since human life is of the utmost value.

Legislators and employer's response to risks posed by the workplace use of nanomaterials would not be possible without the scientific analysis of nanomaterial 
properties. In the context of research, it is worth considering establishing close cooperation between researchers in different fields to exchange information on nanotechnology, taking into account academic independence ([3], p. 36). This social solidarity requires that scientists disseminate nanotechnology research and conduct it with a sense of responsibility for human health. Trust is crucial here ([56], p. 53). It may also be useful to create more stakeholder forums for nanotechnology. This would permit dialogue to take place as part of a broader societal activity, allowing the broadening of knowledge about nanomaterials and developing rules for their use ([57], pp. 126-127). Improved communication on nanotechnology can improve public discourse in this area ([58], p. 151).

Actions are being taken across Europe to exchange information on the characteristics of nanomaterials. Databases of nanomaterials are being developed, which also include toxicity information. The NanoSafety Cluster creates such databases and provides information on the impact of individual nanomaterials on human health or the environment. The eNanoMapper framework, in turn, as an initiative funded by the European Union, makes it possible for scientists to compare the results of their research on engineered nanomaterials. The project involves equipping scientists with the tools necessary to use reliable research methods for nanomaterials in accordance with the relevant standards of the International Organization for Standardization [59]. The content of databases of nanomaterials is not limited to information on the degree of toxicity. For example, at http:// www.pubvinas.com, a public database was established, which is to be a source of knowledge needed for nanoinformation modelling [60].

Such collaboration should have a global reach. The European Union could be a key player here since it has already been undertaking material legislation measures in the area of nanotechnology. Just as the Catholic Church pointed out the need for people to form a community for the good of the workplace ([61], p. 359), so all people should form an international community for the good of the whole world. It is worth considering in this context the need for creating a single international database of nanomaterial properties, based on scientific studies conducted around the world. Such a database could be used to determine which nanomaterials are dangerous or pose a potential risk to human health. Such a tool would expedite the large-scale response to potential threats to the health of workers who work with specific nanomaterials. Standardisation of nanosubstances in the main database utilising the work of researchers from around the globe would help to order the dispersed scientific assessments of nanomaterials.

\section{Conclusions}

The analysis carried out gives rise to several conclusions. Occupational health and safety in the use of nanomaterials are still not properly regulated in Europe. However, several regulations impose specific obligations on employers to provide appropriate working conditions for employees. Among other things, these issues are regulated by European law, but not directly related to work with nanoparticles. In work environments, many unknown aspects of the impact of nanomaterials on living organisms, especially on humans, remain, although some nanomaterials clearly show toxic properties in the light of scientific research. It is, therefore, appropriate to ask how employers should behave, bearing a particular responsibility for the protection of workers' health at work.

Some guidance for employers may include rules that are derived from the teachings of the Catholic Church. Above all, the most important value in the work process is the human being himself. Scientific and technological progress must not be made at the expense of workers' health. From the papal encyclicals, the primacy of man over things clearly emerges. An employee must not be held hostage to science and technology in a way that clearly interferes with the right to life. However, this does not mean that the use of nanomaterials in work environments should now be compltely forbidden due to the potential negative impact of, for example, carbon nanotubes. Total restriction of nanomaterial use would reduce also the use of nanomaterials with properties neutral to workers' health. The formulation of any prohibitions in this area requires careful consideration. There may be a conflict, e.g. between the development of nanomedicine to help protect patients' health and the health and safety of workers using nanoparticles in the manufacture of, for example, medicines. So how to resolve such a tension?

Resolving this tension is predominantly in the hands of the Legislator that should respond proactively by adequate regulations of nanotechnology use to any imminent workplace risks. It is the European level of legislation that is missing, one that would directly deal with specifics of nanotechnology use in the workplace and that 
would define the correct procedure in case of suspected toxicity of a given nanomaterial. From the perspective of exposure in the workplace, it is important to understand the quantity, type and nature of nanoparticles which find their way into the human body. Uncontrolled human exposure to nanomaterials may result in yet unknown risks, which shall require the Legislator to define methods of addressing harmful nanoparticle release scenarios in the workplace, and not only referring to the prudence principle. However, employers are not released from their obligation to formulate themselves adequate $\mathrm{OH} \& \mathrm{~S}$ policies for the workplace. It is important to adopt appropriate occupational exposure parameters for workplaces and define suitable individual and collective protection measures for workers, according to regulations introduced by the Legislator, which are general in nature. Employers should, therefore, via their in-house regulations, introduce adequate procedures for workplace use of nanomaterials, accounting for specific needs regarding the protection of workers' health.

Open Access This article is licensed under a Creative Commons Attribution 4.0 International License, which permits use, sharing, adaptation, distribution and reproduction in any medium or format, as long as you give appropriate credit to the original author(s) and the source, provide a link to the Creative Commons licence, and indicate if changes were made. The images or other third party material in this article are included in the article's Creative Commons licence, unless indicated otherwise in a credit line to the material. If material is not included in the article's Creative Commons licence and your intended use is not permitted by statutory regulation or exceeds the permitted use, you will need to obtain permission directly from the copyright holder. To view a copy of this licence, visit http://creativecommons.org/licenses/by/4.0/.

\section{References}

1. Benkler Y (2005) Technology, law, freedom and development. Indian J of Law and Technology 1:1-14

2. Nielsen KN, Åm TG, Nydal R (2011) Centre and periphery of nano-a Norwegian context. Nanoethics 5:87-98

3. van de Poel I (2008) How should we do nanoethics? A network approach for discerning ethical issues in nanotechnology. Nanoethics 2:25-38

4. Koepsell D (2009) Let's get small: An introduction to transitional issues in nanotech and intellectual property. Nanoethics 3:157-166

5. Timmermans J, Zhao Y, van den Hoven J (2011) Ethics and nanopharmacy: Value sensitive design of new drugs. Nanoethics 5:269-283

6. Regulation (EU) $2017 / 745$ of the European Parliament and of the Council of 5 April 2017 on medical devices, amending Directive 2001/83/EC, Regulation (EC) No $178 / 2002$ and Regulation (EC) No 1223/2009 and repealing Council Directives 90/385/EEC and 93/42/EEC (Text with EEA relevance), OJ 5.05.2017 L 117/1

7. Jarota M (2019) Prawna ochrona zdrowia pracownika przy pracy z nanocząstkami. Uwagi na temat zasadności wprowadzenia europejskich regulacji prawnych. Med Pr 70(5):633-647

8. Regulation (EU) No 1169/2011 of the European Parliament and of the Council of 25 October 2011 on the provision of food information to consumers, amending Regulations (EC) No 1924/2006 and (EC) No 1925/2006 of the European Parliament and of the Council, and repealing Commission Directive 87/250/EEC, Council Directive 90/496/EEC, Commission Directive 1999/10/EC, Directive 2000/13/EC of the European Parliament and of the Council, Commission Directives 2002/67/EC and 2008/5/ EC and Commission Regulation (EC) No 608/2004 (Text with EEA relevance) OJ 22.11.2011 L 304/18

9. Commision Recomendation of 18 October 2011 on the definition of nanomaterial (Text with EEA relevance) (2011/696/EU) OJ 20.10.2011 L 275/38

10. https://euon. echa. europa.eu/general-infor mation. Accessed 25 June 2020

11. van de Voorde M, Tulinski M, Jurczyk M (2017) Engineered nanomaterials: A discussion of the major categories of nanomaterials. In: Mansfield E and Kaiser DL and Fujita $\mathrm{D}$ and Van de Voorde M (eds) Metrology and standardization for nanotechnology. Protocols and industrial innovation. Wiley - VCH, Weinheim

12. https://ec.europa.eu/health/scientific_committees/ emerging_en. Accessed 25 April 2020

13. Heselhaus S (2010) Risk management of nanomaterials: Environmental and consumer protection under existing EC legislation on chemicals. Pesticides and Biocides Environmental Law Rev 12(2):115-131

14. United Nations Economic Commission for Europe, About the GHS. https://www.unece.org/trans/danger/publi/ghs/ ghs_welcome_e.html. Accessed 1 June 2020.

15. Wolbring G, Ball N (2012) Nanoscale science and technology and people with disabilities in Asia: An ability expectation analysis. Nanoethics 6:127-135

16. Council Directive 89/391/EEC of 12 June 1989 on the introduction of measures to encourage improvements in the safety and health of workers at work OJ 29.06.1989 L $183 / 1$

17. Council Directive 98/24/EC of 7 April 1998 on the protection of the health and safety of workers from the risks related to chemical agents at work (fourteenth individual Directive within the meaning of Article 16(1) of Directive 89/391/EEC) OJ EC 5.05.1998 L 131/11

18. Corrigendum to Regulation (EC) No 1907/2006 of the European Parliament and of the Council of 18 December 2006 concerning the Registration, Evaluation, Authorisation and Restriction of Chemicals (REACH), establishing a European Chemicals Agency, amending Directive 1999/45/EC and repealing Council Regulation (EEC) No 793/93 and Commission Regulation (EC) No 1488/94 as well as Council Directive 76/769/EEC and Commission Directives 91/155/EEC, 93/67/EEC, 93/105/EC and 2000/21/EC OJ 29.5.2007 L 136/3 
19. Commission Regulation (EU) 2018/1881 of 3 December 2018 amending Regulation (EC) No 1907/2006 of the European Parliament and of the Council on the Registration, Evaluation, Authorisation and Restriction of Chemicals (REACH) as regards Annexes I, III,VI, VII, VIII, IX, $\mathrm{X}, \mathrm{XI}$, and XII to address nanoforms of substances (Text with EEA relevance.) OJ 4.12.2018 L 308/1

20. Regulation (EC) No 1272/2008 of the European Parliament and of the Council of 16 December 2008 on classification, labelling and packaging of substances and mixtures, amending and repealing Directives 67/548/ EEC and 1999/45/EC, and amending Regulation (EC) No 1907/2006 (Text with EEA relevance) OJ 31.12.2008 L $353 / 1$

21. Directive 2000/54/EC of the European Parliament and of the Council of 18 September 2000 on the protection of workers from risks related to exposure to biological agents at work (seventh individual directive within the meaning of Article 16(1) of Directive 89/391/EEC) OJ 17.10.2000 L 262/21

22. Directive 2004/37/EC of the European Parliament and of the Council of 29 April 2004 on the protection of workers from the risks related to exposure to carcinogens or mutagens at work (Sixth individual Directive within the meaning of Article 16(1) of Council Directive 89/391/EEC) OJ 30.04.2004 L 158/50

23. Mandel GN (2009) Regulating emerging technologies. Law Innov Technol 1:75-90

24. Block N (2007) The very big fuss over very small things: Advising on the state of regulation of nanotechnologies. Tex Environmental Law J 38(1):1-22

25. Langauer-Lewowicka H, Pawlas K (2014) Nonocząstki, nanotechnologia - potencjalne zagrożenia, środowiskowe i zawodowe. Medycyna Środowiskowa - Environmental Medicine 17(2):7-14

26. Martins PR, Dulley RD (2014) Nanotechnology and risks into the workers universe: Some critical reflections. In: Ribeiro M G (ed) Frontiers in occupational health and safety: Changes in the world of work and impacts on occupational health and safety. Bentham Science Publishers, Sao Paulo

27. van Tassel KA, Goldman RH (2011) The growing consumer exposure to nanotechnology in everyday products: Regulating innovative technologies in light of lessons from the past. Conn L Rev 44(2):481-530

28. Stimers $P$ (2008) The implications of recent nanomaterials toxicity studies for the nanotech community. Nanotech L \& Bus 3(5):313-318

29. Herrarte IL, Cela AA (2011), The Precautionary Principle: Regulation needed to confront the risks associated with nanotechnology. In: Uranga MG, de Bustos JCM (eds) Innovation: Economic, social and cultural aspects. Centre for Basque Studies University of Nevada, Reno

30. Jurewicz M (2019) Zasada ostrożności w administracyjnoprawnych regulacjach dotyczących nanomateriałów. Elipsa Dom Wydawniczy, Warsaw

31. Consolidated versions of the Treaty on European Union and the Treaty on the Functioning of the European Union OJ 26.10.2012 C 326/47

32. Judgment of 26. 11. 2002 - joined cases $\mathrm{t}-74 / 00$, $\mathrm{t}-76 / 00$, $\mathrm{t}-83 / 00$ to $\mathrm{t}-85 / 00, \mathrm{t}-132 / 00, \mathrm{t}-137 / 00$ and $\mathrm{t}-141 / 00$ Judgment of the Court of first instance (second chamber, extended composition) 26 November 2002. http://curia.europa.eu/ juris/showPdf.jsf;jsessionid=98779FA683A7B7EA49B1 65099F027C07? text $=\&$ docid $=47533 \&$ pageIndex $=0 \&$ doclang $=$ en $\&$ mode $=1$ st $\&$ dir $=\& o c c=$ first $\&$ part $=1 \& \mathrm{cid}=$ 7188759. Accessed 25 June 2020

33. Communication from the Commission on the precautionary principle, Brussels, 2.2.2000 COM(2000) 1 final, https://eurlex.europa.eu/legal-content/EN/TXT/PDF/?uri=CELEX: 52000DC0001\&from=PL. Accessed 25 June 2020

34. Mattarolo MG, Muratorio A (2010) The protection of workers exposed to nanoparticles: Reflections on European and Italian soft and binding regulations. SCRIPTed 7(3):515-531

35. Polish Labour Code. http://www.en.pollub.pl/files/17/ attachment/98_Polish-Labour-Code,1997.pdf. Accessed 25 June 2020

36. Gazso A, Fries R (2012) Nanomaterials and occupational safety: An overview. European J of Risk Regulation 3(4):594-600

37. Reichow A (2016) Risk, uncertainty, and learning in nanomaterials regulation: An analytical framework. European J of Risk Regulation 7(3):502-516

38. Nasu H, Faunce T (2012) Nano-safety or nano-security? Reassessing Europe's nanotechnology regulation in the context of international security law. European J of Risk Regulation 3(3):416-420

39. Reimhul E (2017) Nanoparticle risks and identification in a world where small things do not survive. Nanoethics 11:283-290

40. Shumpert BL, Wolfe AK, Bjornstad DJ et al (2014) Specificity and engagement: Increasing ELSI's relevance to nano-scientists. Nanoethics 8:193-200

41. Pope Leo XIII (1891) Encyclical Rerum Novarum. http://www.vatican.va/content/leo-xiii/en/encyclicals/ documents/hf_1-xiii_enc_15051891_rerum-novarum. html. Accessed 15 Feb 2020

42. Pope Paul VI (1965) Pastoral Constitution on the Church in the modern world Gaudium et Spes. http://www.vatican. va/archive/hist_councils/ii_vatican_council/documents/ vat-ii_cons_19651207_gaudium-et-spes_en.html. Accessed 15 Feb 2020

43. Pope John XXIII (1963) Encyclical Pacem in Terris. http://www.vatican.va/content/john-xxiii/en/encyclicals/ documents/hf_j-xxiii_enc_11041963_pacem.html. Accessed 15 Feb 2020

44. Pope Paul VI (1967) Encyclical Populorum Progressio. http://www.vatican.va/content/paul-vi/en/encyclicals/ documents/hf_p-vi_enc_26031967_populorum.html. Accessed 15 Feb 2020

45. Strzeszewski C (1969) Integralny rozwój człowieka według wskazań encykliki Pawła VI Populorum Progressio. Zeszyty Naukowe KUL XII 2:17-22

46. Pope John Paul II (1979) Encyclical Redemptor Hominis. http://www.vatican.va/content/john-paul-ii/en/encyclicals/ documents/hf_jp-ii_enc_04031979_redemptor-hominis. html. Accessed 15 Feb 2020

47. Szostek A (1985-1986) Antropologia „Redemptor Hominis". Roczniki Filozoficzne XXXIII-XXXIV(2):41-55

48. Styczeń T (1978) Bóg o Człowieku. Na marginesie encykliki Redemptor Hominis Summarium 7(27):25-33 
49. Pope John Paul II (1981) Encyclical Laborem Exercens. http://www.vatican.va/content/john-paul-ii/en/encyclicals/ documents/hf_jp-ii_enc_14091981_laborem-exercens. html. Accessed 15 Feb 2020

50. Cardinal Stefan Wyszyński (1983) Nauczanie społeczne Kardynała Stefana Wyszyńskiego - wybór tekstów. Wydział Inicjatyw Społeczno-Katolickich Stowarzyszenie PAX, Warszawa

51. https://cordis.europa.eu/article/id/400909-nanomedicineinnovative-ways-of-treating-challenging-conditions. Accessed 2 Nov 2020

52. Stolarczyk I (1998) Postęp i rozwój w nauczaniu społecznym Kościoła. Biblos, Tarnów

53. Kermisch C (2012) Do new ethical issues arise at each stage of nanotechnological development? Nanoethics 6:29-37

54. Pope Benedict XVI (2009) Encyclical Caritas in Veritate. http://www.vatican.va/content/benedict-xvi/en/encyclicals/ documents/hf_ben-xvi_enc_20090629_caritas-in-veritate. html. Accessed 15 Feb 2020

55. Marx R (2009) Kapitał. Mowa w obronie człowieka. Serafin J CSsR (transl.). Homo Dei, Kraków
56. Myskja BK (2011) Trustworthy nanotechnology: Risk, engagement and responsibility. Nanoethics 5:49-56

57. Åm H (2011) Trust as glue in nanotechnology governance networks. Nanoethics 5:115-128

58. Miah A (2017) Nanoethics, science communication, and a fourth model for public engagement. Nanoethics 11:139-152

59. http://www.enanomapper.net/about. Accessed 2 Nov 2020

60. Yan X, Sedykh A, Wang W et al (2020) Construction of a web-based nanomaterial database by big data curation and modeling friendly nanostructure annotations. Nat Commun 11:1-10. https://doi.org/10.1038/s41467-020-16413-3

61. Charles R, Maclaren D (1995) Kościół w świecie współczesnym. Nauczanie społeczne Kościoła w świetle Soboru Watykańskiego II. Grosfeld J (transl.). W drodze, Poznań

Publisher's Note Springer Nature remains neutral with regard to $j$ urisdictional claims in published maps and institutional affiliations. 